\title{
Developing River Tourism in Palangka Raya Municipality Central Kalimantan Province
}

\author{
Nenden Dianawati \\ Sekolah Tinggi Pariwisata Bandung, Indonesia \\ ned@stp-bandung.ac.id
}

\begin{abstract}
Developing River Tourism in Palangka Raya Municipality Central Kalimantan Province. Currently river tourism is increasingly developing in various regions in Indonesia aside from maritime. Kalimantan Island as the largest island in Indonesia possess abundant potential including the river and it trigger the Regional Government, especially Palangka Raya Municipality in drafting Regional Regulations on Tourism Strategic Areas (KSP). This guideline however, has not fully functionate as their reference in developing tourism destinations in the Capital City of Central Kalimantan Province. This research aiming to provide practical guidance in developing a tourism destinations in KSP 2 Tumbang Tahai which is the focus of the main river tourism activities, with education and conservation as development theme. Qualitative research methods are conducted to identify the potentials by applying previous research approaches that exert parameters of river tourism resources, tourist activities, quality of riverbanks, as well as facilities and infrastructure. The results of the study revealed the availability of the four parameters in preparing recommendations on physical aspects development including zoning layout. In the future, this research is best continued by reviewing non-physical aspects in sharpening analysis and reconcile recommendations, so that the Regional Government has a set of tools in establishing work plans to improve the quality of river tourism in Palangka Raya, becoming Indonesia's leading tourism icon.
\end{abstract}

Keywords

River Tourism; Developing Strategy; Regional Destination

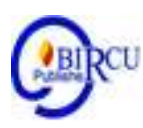

\section{Introduction}

River tourism has been enormously developed in various regions and become a tourist theme to attract tourist visits (Prideaux, 2009). In the Southeast Asian region, the Chao Praya River is able to attract tourist visits in Thailand by cultural approach and historical activities. Meanwhile, the Mekong River was developed with activities on the express boat to create an attraction for tourists visiting Vietnam.

While in the European region, the Amsterdam canal is used as a means of transportation and Amsterdam City Tourism. Furthermore, the City of Venice is also famous for its Venice channels for tourist sightseeing activities. River tourism also develops on the American continent through the Amazon River and the Mississippi River which has natural and cultural values.

Indonesia however, as an archipelago has the potential to develop river tourism. Kalimantan Island which is the largest island has the similar character of rivers such as those in Thailand, Vietnam and even the Amazon. The Kahayan River which crosses Palangka Raya City in Central Kalimantan Province, has a length of more than $600 \mathrm{KM}$ and a width of 450 M (BPS, Central Kalimantan Province, 2018) with one of the Rungan 
tributaries currently not fully developed into a regional leading destination as a revenue generator from the tourism sector.

At the regional level, tourism development in Palangka Raya City refers to the Regional Regulation of Palangka Raya Municipality Number 11 year of 2017. In developing tourism, Palangka Raya City divides into four Strategic Tourism Areas (KSP) consisting of KSP 1 Sei Gohong, KSP 2 Tumbang Tahai, KSP 3 Pahandut and KSP 4 Kalampangan. In KSP 2 Tumbang Tahai consist of ten tourism destinations (DTW) : (1) Sei Gohong Tourism Village, (2) Kanarakan Tourism Village, (3) Kaja Island, (4) Sei Batu, (5) Pura Sali Paseban Batu, (5) 6) Bukit Karmel, (7) Batu Banama, (8) Nyaru Menteng Campsite, (9) Bukit Tangkiling Nature Tourism Park and (10) Tahai Lake. The area is traversed by the Kahayan River and the Rungan River which, according to the Regional Regulation of Palangka Raya Municipality Number 11 year of 2017, this area was developed as an educational themed tourism that includes cultural education and conservation education.

DTW at KSP 2 Tumbang Tahai also has river tourism potential. The ten DTWs are crossed by Kahayan River and Rungan River. The Kahayan River and the Rungan River in the concept of rivertourism are included in the type of River Management - Disposal of Waste which means that the Kahayan River currently has a function for waste disposal and the surrounding industry. In other parameters, the Kahayan River is also used as a means of transportation on inter-city and regional routes that have not been reached by land transportation modes with a river width of 200 meters. This means that the existence of the Kahayan River and the Rungan River have not been considered to provide added value in tourism.

Integrated tourism management of the Kahayan River has not been properly developed due to the weak coordination between stakeholders in this case the local government, the private sector and the local community in building the image of Palangka Raya City as one of the best river tourism destinations in Indonesia. (Source: results of observations of researchers as staff of the Marketing Department of Culture and Tourism of Palangka Raya Municipality, 2010-2014).

Another influencing factor is the lack of awareness of the community and the Government in optimizing the potential for natural, historical, cultural and local architecture of the Tangkiling Village and Sei Gohong Tourism Village causing the low quality of the Tourism Attraction in the village. The village needs to be developed into DTW considering Tangkiling Village is the entrance of tourists in conducting river tourism. For this reason, it is necessary to develop thematic tourism in the form of river tourism on the Kahayan River and the Rungan River in Palangka Raya responding challenges in Tourism Attraction quality, integration management and public awareness and the government of Palangka Raya.

The river tourism approach has been described by several researchers. One of them is that states that the approach aspects for the development of the western region of the Brantas River are destination attractiveness, community support around the area, facilities and infrastructures or river tourism facilities and infrastructure. Meanwhile, (Ayuningtyas, 2010) stated that the river code development, DI Province. Yogyakarta is done by mapping activities and locations. Research from (Ayuningtyas, 2010) is in line with Orams's Recreation Opportunity Spectrum (ROS) concept which states that the development of river tourism in Sweden is carried out with an approach to the aspects of experience, environment, location and examples of activities. Then, (Amnuay, 2013) states that the quality of riverbank affects the quality of tourism and the number of tourist visits to the Mekong River, Vietnam. Furthermore, the river tourism resource approach was developed 
by (Orams, 1999) which states that the aspect of discussion in river tourism resources is island resources, animal resources and cultural resources.

\section{Review of Literature}

\subsection{Rivertourism Resources}

Rivertourism resources consist of island resources, animal resources, cultural resources and resources management. In the aspect of island resources, even though river tourism development is mostly small scale and ecotourism based, it is important to maintain information resources at all scales. In addition, there is a need for more complete information to interpret the impacts of regional tourism. Considering that there are many threats to developing countries globally, such as deforestation and the destruction of the endemic flora of the region. Fennel (1999) stated that tourism resources are all things that have the potential to be developed in supporting river tourism activities, both directly and indirectly. In the aspect of animal resources tourism offers some potential for finding out more about animals. Collecting data in this way can lead to greater awareness of natural resources.

The process of interaction with nature will be more controlled and cooperation between operators and conservationists is a good example of sustainable nature-based tourism. Through a tour by offering a good opportunity to collect data about animals (Commonwealth of Australia, 2002). In the aspect of cultural resources, river tourism resources are not only natural resources, there are various anthropological resources above and below the water surface that can form many attractions. The river can be the location of social gatherings and celebrations of local people. Protection of tourism resources is prioritized. Various cultural resources such as artifacts, heritage of historic buildings, visual and performing arts, craftsmanship, literary and lifestyle traditions, knowledge and skills, as well as beliefs and values. Social interaction is an important part of the tourism experience (Leiper, 1995).

In the aspect of resource management the growing popularity of the river tourism experience shows the increasing demand for resources. The pressure comes from existing conflicts between different groups of river users, between water-based tourism and more consumptive river users. The only way to resolve conflicts is through effective management of resources. The key to managing river resources for tourism users and other users is dynamic information gathering. Community-based resource management and community participation are seen not only as a way to improve resource management but also as a way to alleviate poverty (Pomeroy, 1995).

\subsection{Tourist Activities}

Activities undertaken by tourists while enjoying nature include three groups as explained in the theory of Recreation Opportunities Spectrum (ROS) and Water Recreation Opportunities Spectrum (WROS) below. Ackerman, R and Haas, G. (2004) divide the activity categories into water-based activities and water-related land activities. Waterbased activities are basically all activities carried out by interacting continuously with the water environment in this case rivers. Whereas water-related land activities are activities carried out on land but are closely related to water. Some activities are explained in the following figure. 


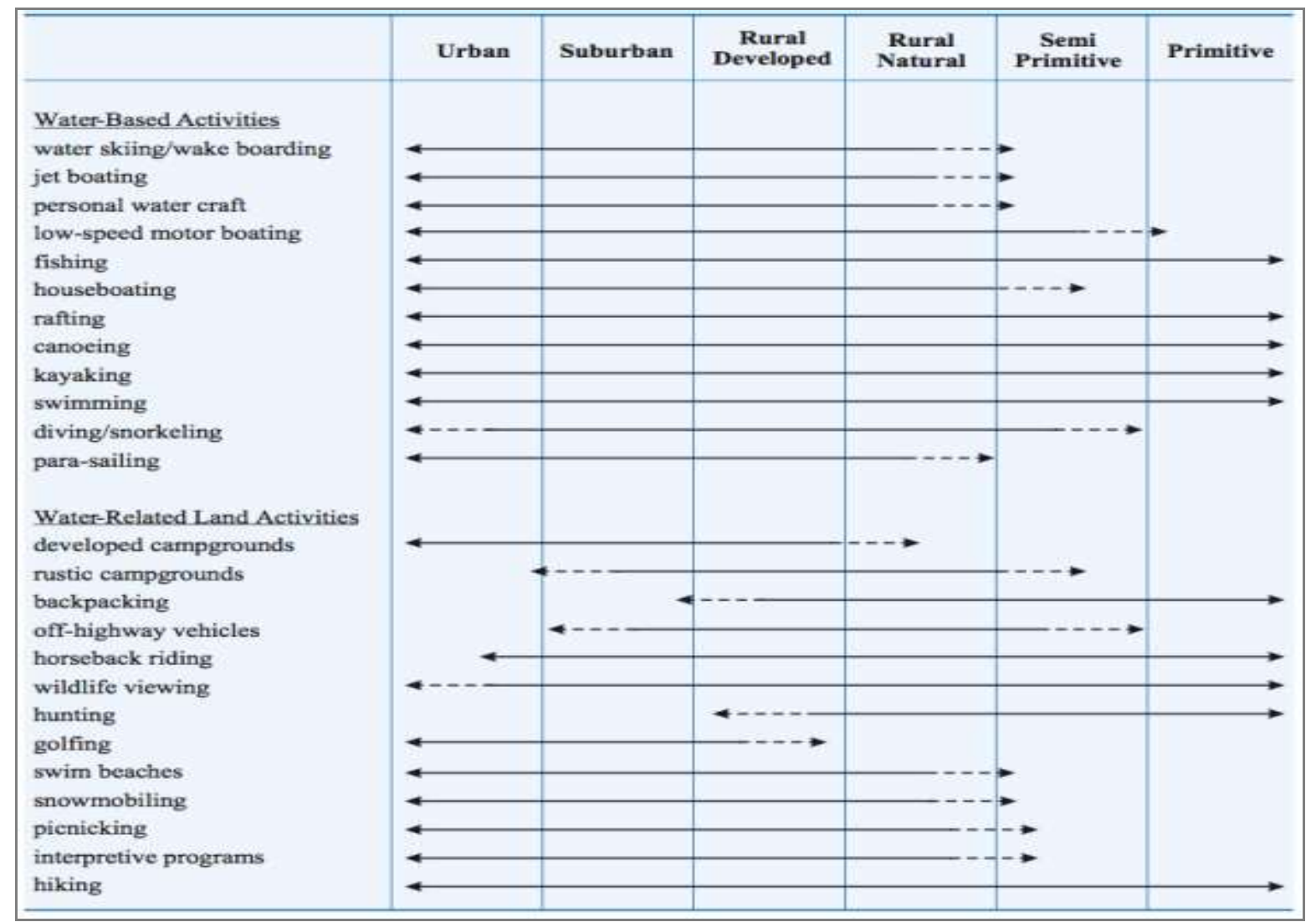

Source: Ackerman, R and Haas, G. (2004)

Figure 1. Tourist Activities According to WROS

\subsection{Quality of Riverbank}

Ten quality spaces for public destinations are the concepts used by PPS (Project for Public Space) to start the place making process. The basic idea is not to create only one good place in the neighbourhood. The basic idea of public space must be able to fulfil some of the aspects outlined in the following diagram.

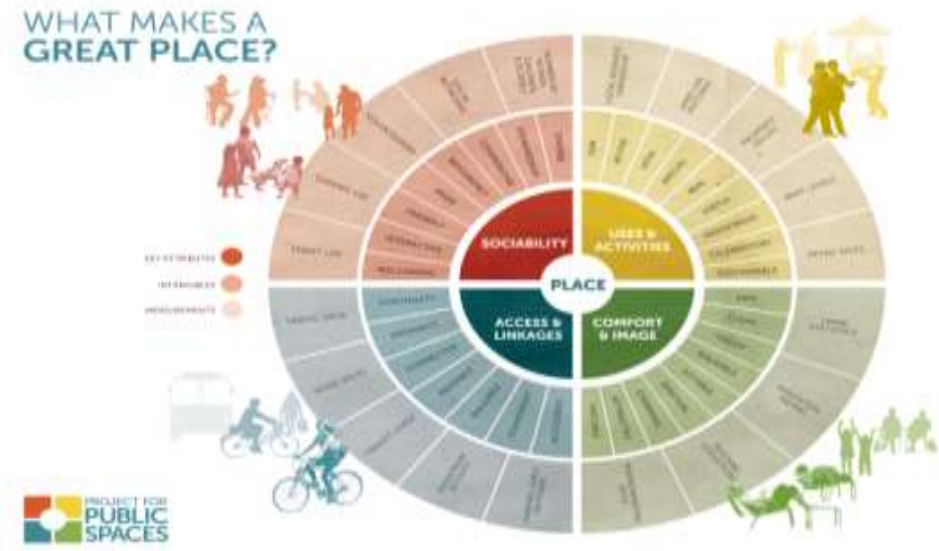

Source: Project for Public Spaces (pps.org)

Figure 2. The Place Diagram 


\subsection{Facilities and Infrastructures}

In describing facilities and infrastructure, Lothar A. Kreck in Yoeti (1996) Divide tourism infrastructure into two main groups covering economic infrastructure (transport, communication, electricity, clean water, energy) and social infrastructure (education, health, security, services). Besides dividing tourism facilities into three main groups which include basic facilities (travel agents, hotels, restaurants), supplements (tennis courts, golf, swimming pools, hunting areas), supporting (casino, club).

\section{Research Methods}

This research contains social and dynamic problems. The research process and understanding of the research problem are investigated by research procedures that produce descriptive data (Moleong, 2012). The descriptive data produced findings of physical and non-physical conditions which were used as material for potential analysis in preparing recommendations for developing river tourism in Palangka Raya. From the results of descriptive data, the researcher seeks to describe the results of the research or the findings under study which are then described in the form of a discussion of the discussion.

Sources of information came from four groups of respondents representing the government, business actors and local communities in the KSP 2 Tumbang Tahai area. Data collection techniques used are observation, interviews, study documentation, and data collection through secondary data. The data is then analysed.

\section{Results and Discussion}

Tourism development in Palangka Raya refers to the Regional Regulation of Palangka Raya Municipality Number 11 of 2017. In the development of tourism, Palangka Raya divides into five Strategic Tourism Areas (KSP) consisting of KSP 1 Sei Gohong, KSP 2 Tumbang Tahai, KSP 3 Pahandut and KSP 4 Kalampangan. The division of these regions can be clearly seen in the following figure:

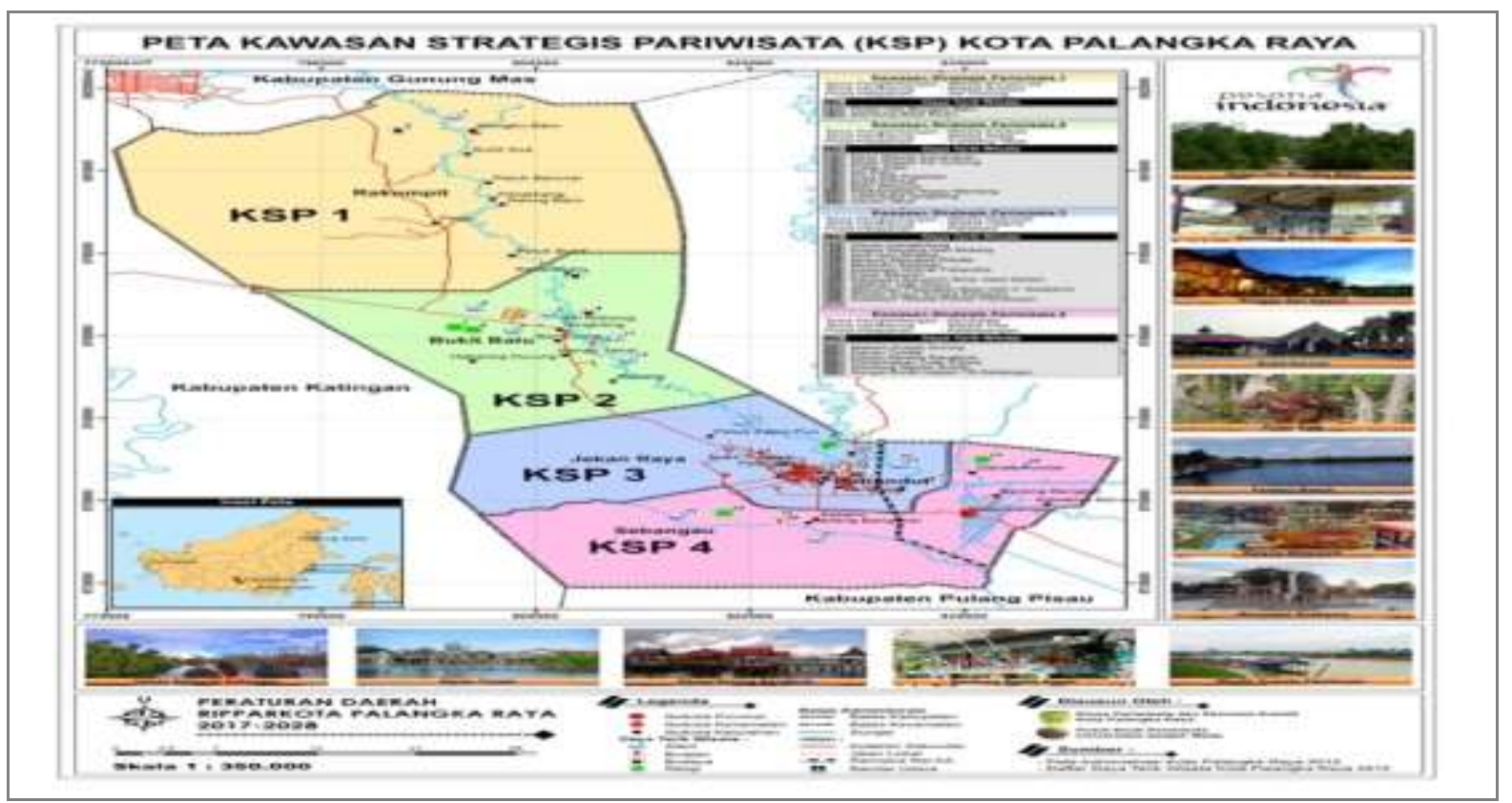

Source: Processing Data, 2018.

Figure 3. Strategic Tourism Areas (KSP) in Palangka Raya 
In KSP 2 Tumbang Tahai in Palangka Raya there are ten DTWs consisting of (1) Sei Gohong Tourism Village, (2) Kanarakan Tourism Village, (3) Kaja Island, (4) Sei Batu, (5) Sali Paseban Batu Temple, (5) 6) Bukit Karmel, (7) Batu Banama, (8) Nyaru Menteng Campsite, (9) Bukit Tangkiling Nature Tourism Park and (10) Tahai Lake. In this area developed as tourism-themed education and conservation.

\subsection{Rivertourism Resources}

The results of the identification of river tourism resources or rivertourism resources consisting of island resources, animal resources, cultural resources and resource management are explained in the following table,

Table 1. Rivertourism Resources Identification

\begin{tabular}{|c|c|c|c|c|c|}
\hline \multirow{2}{*}{ No } & \multirow{2}{*}{ Daya Tarik Wisata } & \multicolumn{4}{|c|}{$\begin{array}{c}\text { Sumber Daya Wisata Sungai } \\
\text { (Rinertonrism Resources) }\end{array}$} \\
\hline & & $\begin{array}{c}\text { Island } \\
\text { Resources }\end{array}$ & $\begin{array}{l}\text { Animal } \\
\text { Resources }\end{array}$ & $\begin{array}{l}\text { Cultural } \\
\text { Resources }\end{array}$ & $\begin{array}{c}\text { Resources } \\
\text { Management }\end{array}$ \\
\hline 1 & Dea Wizata Sei Gohong & $\sqrt{ }$ & - & $\sqrt{ }$ & $\sqrt{l}$ \\
\hline 2 & Desa Wisata Kanaralan & $\sqrt{ }$ & $\sqrt{4}$ & $\sqrt{1}$ & $\sqrt{ }$ \\
\hline 3 & Pulau Kaja & - & $\sqrt{1}$ & - & $\sqrt{1}$ \\
\hline 4 & Sei Batu & $\sqrt{ }$ & - & - & $\sqrt{1}$ \\
\hline 5 & Pura Sali Basban Batu* & $\sqrt{4}$ & - & $\sqrt{1}$ & $\sqrt{1}$ \\
\hline 6 & Bukit Kamel" & $\sqrt{ }$ & - & $\sqrt{t}$ & $\sqrt{ }$ \\
\hline 7 & Batu Banama* & $\sqrt{ }$ & - & $\sqrt{ }$ & $\sqrt{ }$ \\
\hline 8 & $\begin{array}{l}\text { Perkemahan Nyanu } \\
\text { Menteng" }\end{array}$ & $\sqrt{ }$ & - & - & $\sqrt{ }$ \\
\hline 9 & $\begin{array}{l}\text { Taman Wizata Alam } \\
\text { Bukit Tangkiling* }\end{array}$ & $\sqrt{7}$ & $\sqrt{1}$ & - & $\sqrt{ }$ \\
\hline 10 & Danau Tahai & $\sqrt{7}$ & $\sqrt{ }$ & - & $\sqrt{1}$ \\
\hline
\end{tabular}

Source: Research Process Data, 2018. Note: $(\sqrt{ })$ exists, $(-)$ does not exist, $\left({ }^{*}\right)$ does not cross the river

The table above shows that the DTW which has the power of river tourism resources (rivertourism resources) is Kanarakan Tourism Village. In KSP 2 Tumbang Tahai, this village has the farthest distance from the center of Palangka Raya City with very limited access and can only be reached by water transportation for 2 hours from the Soekarno pier. Second is Sei Gohong Tourism Village, which has better access with a travel time of 30 minutes from the city center using a vehicle and is crossed by the Rungan river also in the same area as DTW Kaja Island. Whereas DTW which has the weakest river tourism resources (rivertourism resources) is Bukit Karmel. Besides being not crossed by the river, this place functions more as a religious tourism destination with certain restrictions in development aspects.

\subsection{Tourist Activities}

The results of the identification of tourist activities in this case are described according to the Water Recreation Opportunities Spectrum (WROS) approach described in the following table. 
Table 2. Tourist Activities Identification

\begin{tabular}{|c|c|c|c|c|c|c|c|c|c|c|}
\hline No & 1 & 2 & 3 & 4 & 5 & 6 & 7 & 8 & 9 & 10 \\
\hline $\begin{array}{c}\text { Nama Daya Tarik Wrata } \\
\text { Aktritzs Weats }\end{array}$ & $\begin{array}{l}\text { Desa Wisata } \\
\text { Sei Gohong }\end{array}$ & $\begin{array}{l}\text { Desa Wisata } \\
\text { Kanaralcan }\end{array}$ & PulauKaja & Sei Batu & $\begin{array}{c}\text { Pura Sali } \\
\text { Basebau Batu* }\end{array}$ & $\begin{array}{l}\text { Bulit } \\
\text { Karmel* }\end{array}$ & $\begin{array}{c}\text { Batu } \\
\text { Banama* }\end{array}$ & $\begin{array}{l}\text { Perkemahas } \\
\text { Nyaru } \\
\text { Menteng* }\end{array}$ & $\begin{array}{l}\text { Taman Wizata } \\
\text { Alam Bukit } \\
\text { Tangkifing* }\end{array}$ & Danau Tabai \\
\hline \multicolumn{11}{|c|}{ Water Based Activities } \\
\hline Wolty thiltghak bourding & 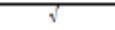 & 7 & $\cdot$ & $\sqrt{ }$ & $T^{\prime}$ & $\cdot$ & $\cdot$ & $\cdot$ & $\cdot$ & 1 \\
\hline Jet bouting & ง & 1 & $\cdot$ & $\cdot$ & $\cdot$ & $\cdot$ & 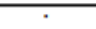 & $\cdot$ & - & 7 \\
\hline Personal water craft: & 8 & 8 & $\frac{1}{4}$ & $\cdot$ & $\cdot$ & $\bar{\sigma}$ & $\bar{\sigma}$ & $\bar{\sigma}$ & $\bar{\sigma}$ & 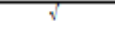 \\
\hline Low-speed motor bouting & $\frac{1}{4}$ & $\frac{1}{4}$ & t & $\cdot$ & $\bar{\sigma}$ & $\cdot$ & $\bar{\sigma}$ & $\bar{\sigma}$ & $\bar{\sigma}$ & 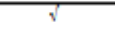 \\
\hline Fishing & 7 & 1 & 7 & $\cdot$ & $\cdot$ & $\cdot$ & $\cdot$ & $\cdot$ & $\cdot$ & 7 \\
\hline Houseboating & 1 & 1 & $\frac{1}{4}$ & $\cdot$ & . & . & . & - & . & ป \\
\hline Rafifing & 8 & $\cdot$ & $\bar{\sigma}$ & 7 & - & $\bar{\sigma}$ & $\cdot$ & $\bar{\sigma}$ & $\bar{\sigma}$ & $\sqrt{ }$ \\
\hline Canoeing & $\frac{1}{4}$ & 1 & 1 & $\cdot$ & . & . & . & $\cdot$ & . & 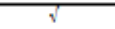 \\
\hline Kavaking & $\frac{1}{4}$ & 1 & $\frac{1}{4}$ & $\cdot$ & $\cdot$ & $\cdot$ & - & $\cdot$ & $\cdot$ & ง \\
\hline Srimming & $\cdot$ & $\cdot$ & $\overline{-}$ & 与 & $\overline{-}$ & $\overline{-}$ & - & $\cdot$ & $\cdot$ & $\cdot$ \\
\hline Diving/smorkeling & $\bar{\sigma}$ & $\bar{\sigma}$ & $\bar{\sigma}$ & $\bar{\sigma}$ & $\cdot$ & $\cdot$ & $\cdot$ & 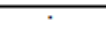 & $\bar{\cdot}$ & $\cdot$ \\
\hline Para-saling & $\cdot$ & $\cdot$ & $\cdot$ & $\cdot$ & $\cdot$ & $\cdot$ & $\cdot$ & $\bar{\cdot}$ & $\bar{\cdot}$ & $\cdot$ \\
\hline \multicolumn{11}{|c|}{ Water Related Land Activities } \\
\hline Developed campgrouná & $\bar{\sigma}$ & $\bar{\sigma}$ & $\bar{\sigma}$ & $\cdot$ & \begin{tabular}{|c|}
$\cdot$ \\
\end{tabular} & $\bar{\sigma}$ & $\bar{\sigma}$ & $\checkmark$ & $\bar{\sigma}$ & $\cdot$ \\
\hline Rustic campg gutudót & $\cdot$ & $\cdot$ & $\cdot$ & $\cdot$ & $\overline{-}$ & 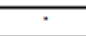 & $\cdot$ & 7 & $\cdot$ & $\bar{\cdot}$ \\
\hline Backyacking & $\sqrt{1}$ & $\sqrt{6}$ & $\bar{\sigma}$ & 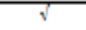 & 7 & ง & $\sqrt{1}$ & 7 & $\sqrt{7}$ & 7 \\
\hline Off-hightway vehicles & $\cdot$ & $\cdot$ & $\cdot$ & $\cdot$ & $\cdot$ & $\cdot$ & $\cdot$ & $\cdot$ & $\bar{*}$ & $\cdot$ \\
\hline Horseback riaing & $\cdot$ & $\cdot$ & $\cdot$ & $\cdot$ & $\bar{\cdot}$ & $\cdot$ & $\cdot$ & $\cdot$ & $\cdot$ & $\cdot$ \\
\hline Willdilie viewing & 1 & 7 & ง & $\cdot$ & $\bar{c}$ & $\cdot$ & - & $\cdot$ & 1 & $\cdot$ \\
\hline Hunting & 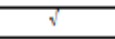 & 7 & $\cdot$ & $\cdot$ & $\cdot$ & $\cdot$ & $\cdot$ & $\cdot$ & $\cdot$ & 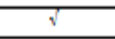 \\
\hline Golfing & $\cdot$ & $\cdot$ & $\cdot$ & $\cdot$ & $\cdot$ & $\cdot$ & $\cdot$ & $\cdot$ & $\cdot$ & $\cdot$ \\
\hline Swin beaches & $\bar{\sigma}$ & $\cdot$ & $\bar{\sigma}$ & $\cdot$ & $\cdot$ & $\cdot$ & $\cdot$ & $\cdot$ & $\cdot$ & $\cdot$ \\
\hline Srow mobting & $\overline{-}$ & $\cdot$ & $\bar{\sigma}$ & $\cdot$ & $\bar{\sigma}$ & $\cdot$ & $\cdot$ & $\cdot$ & $\cdot$ & $\cdot$ \\
\hline Picnicking & $\sqrt{7}$ & 7 & $\cdot$ & $\sqrt{1}$ & $\cdot$ & $\sqrt{7}$ & $\bar{\cdot}$ & $\sqrt{7}$ & $\sqrt{ }$ & $\sqrt{1}$ \\
\hline Thteryretive Programs & 1 & 1 & - & ป & จ & จ & 7 & 7 & ง & 1 \\
\hline Hiking & 7 & 7 & $\cdot$ & 7 & 7 & 7 & 7 & 7 & 7 & 7 \\
\hline
\end{tabular}

Source: Research Process Data, 2018. Note: $(\sqrt{ })$ exists, $(-)$ does not exist, $\left({ }^{*}\right)$ does not cross the river

The table above shows that DTW which has the power of tourist activities (tourist activities) is Sei Gohong Tourism Village. The village, which is passed by the Rungan river, has quite good access with a travel time of 30 minutes from the city center by vehicle. In addition to completing the wildlife viewing activity, this village is also in the same area as DTW Kaja Island to observe Orang Utans from a boat or a riverboat tour boat.

Whereas DTW which has the weakest tourist activity is Batu Banama. Besides being not crossed by the river, this place functions more as a cultural tourism destination with certain restrictions in development aspects.

\subsection{Quality of Riverbank}

The results of identification using parameters developed by Project for Public Spaces (pps.org) which explain ten quality spaces for public destiny can be seen in the following table : 
Table 3. Quality of Riverbanks Identification

\begin{tabular}{|c|c|c|c|c|c|c|c|c|c|c|c|}
\hline \multirow[b]{2}{*}{ No } & \multirow[b]{2}{*}{$\begin{array}{l}\text { Nama Daya Tarik } \\
\text { Wisata }\end{array}$} & \multicolumn{10}{|c|}{ Kualitas Ruang TepiSungai (Quality of Riverbanks) } \\
\hline & & $\begin{array}{c}\text { Lingkungan } \\
\text { Bangunan } \\
\text { Sekitar }\end{array}$ & $\begin{array}{l}\text { Ketersediaan } \\
\text { Ruang } \\
\text { Terbuka }\end{array}$ & $\begin{array}{c}\text { Aktivitas } \\
\text { Sepanjang } \\
\text { Tahun }\end{array}$ & $\begin{array}{c}\text { Fleksibilitas } \\
\text { Desain } \\
\text { Fasilitas } \\
\text { Terhadap } \\
\text { Ragam } \\
\text { Aktivitas } \\
\end{array}$ & \begin{tabular}{c|} 
Elemen \\
Pemicu \\
Kreativitas \\
dan \\
Kesenangan \\
Wisatawan \\
\end{tabular} & $\begin{array}{c}\text { Aksesibilitas } \\
\text { DTW } \\
\text { dengan } \\
\text { sungai }\end{array}$ & $\begin{array}{c}\text { Keberadaan } \\
\text { Identitas } \\
\text { Lokal }\end{array}$ & $\begin{array}{c}\text { Keberadaan } \\
\text { Daya Tarik } \\
\text { Air }\end{array}$ & $\begin{array}{c}\text { Keberadaan } \\
\text { Bangunan } \\
\text { Ikonik dan } \\
\text { Multifungsi }\end{array}$ & $\begin{array}{l}\text { Ketersediaan } \\
\text { Pengelolaan }\end{array}$ \\
\hline 1 & $\begin{array}{l}\text { Desa Wisata Sei } \\
\text { Gohong }\end{array}$ & $\sqrt{ }$ & $\sqrt{ }$ & $\sqrt{ }$ & $\sqrt{ }$ & $\sqrt{ }$ & $\sqrt{ }$ & $\sqrt{ }$ & $\sqrt{ }$ & $\sqrt{ }$ & $\sqrt{ }$ \\
\hline 2 & Desa Wisata Kanarakan & $\sqrt{ }$ & $\sqrt{ }$ & $\sqrt{ }$ & - & $\sqrt{ }$ & $\sqrt{ }$ & $\sqrt{ }$ & $\sqrt{ }$ & $\sqrt{ }$ & $\sqrt{ }$ \\
\hline 3 & $\begin{array}{l}\text { Pulau Kaja } \\
\text { Paj }\end{array}$ & - & - & - & $\cdot$ & - & $\sqrt{ }$ & $\sqrt{ }$ & $\sqrt{ }$ & $\cdot$ & $\sqrt{ }$ \\
\hline 4 & Sei Batu & $\sqrt{ }$ & $\sqrt{ }$ & $\sqrt{ }$ & $\sqrt{ }$ & $\sqrt{ }$ & $\sqrt{ }$ & $\sqrt{ }$ & $\sqrt{ }$ & $\cdot$ & $\sqrt{ }$ \\
\hline 5 & $\begin{array}{l}\text { Pura Sali Baseban } \\
\text { Batu }^{*}\end{array}$ & $\cdot$ & $\sqrt{ }$ & $\cdot$ & $\cdot$ & $\sqrt{ }$ & $\cdot$ & $\cdot$ & $\cdot$ & $\sqrt{ }$ & $\sqrt{ }$ \\
\hline 6 & Bukit Karmel $^{*}$ & $\sqrt{ }$ & $\sqrt{ }$ & $\sqrt{ }$ & $\sqrt{ }$ & $\sqrt{ }$ & $\cdot$ & - & $\cdot$ & $\sqrt{ }$ & $\sqrt{ }$ \\
\hline 7 & Batu Banama ${ }^{8}$ & - & $\sqrt{ }$ & - & - & $\sqrt{ }$ & - & $\sqrt{ }$ & - & - & $\sqrt{ }$ \\
\hline 8 & $\begin{array}{l}\text { Perkemahan Nyaru } \\
\text { Menteng* }\end{array}$ & $\sqrt{ }$ & $\sqrt{ }$ & $\cdot$ & $\sqrt{ }$ & $\sqrt{ }$ & $\cdot$ & $\cdot$ & $\cdot$ & $\cdot$ & $\sqrt{ }$ \\
\hline 9 & $\begin{array}{l}\text { Taman Wisata Alam } \\
\text { Bukit Tangkiling* }\end{array}$ & $\sqrt{ }$ & $\sqrt{ }$ & $\cdot$ & - & $\sqrt{ }$ & $\cdot$ & $\sqrt{ }$ & $\cdot$ & $\cdot$ & $\sqrt{ }$ \\
\hline 10 & Danau Tahai & $\sqrt{ }$ & $\sqrt{ }$ & - & $\sqrt{ }$ & $\sqrt{ }$ & $\sqrt{ }$ & $\sqrt{ }$ & $\sqrt{ }$ & $\cdot$ & $\sqrt{ }$ \\
\hline
\end{tabular}

Source: Research Process Data, 2018. Note: $(\sqrt{ })$ exists, (-) does not exist, (*) does not cross the river

The table above shows that the DTW that has the quality of riverbanks is Sei Gohong Tourism Village. Sei Gohong Tourism Village meets the ten parameters of the quality of public space destinations that can provide comfort to tourists and social and economic benefits for the local community.

Whereas DTW which has the weakest riverside space quality is Kaja Island. In addition, because this island is a pre-release Orangutan conservation area surrounded by the Rungan river, this place serves more as a destination for environmentalists to wildlife researchers with strict restrictions in development aspects.

\subsection{Facilitites and Infrastructures}

The results of the identification of facilities and infrastructure are explained in the following table:

Table 4. Facilities and Infrastructures Identification

\begin{tabular}{|c|c|c|c|c|c|c|c|c|c|c|c|c|c|}
\hline \multirow{2}{*}{$\mathrm{S}_{0}$} & \multirow{2}{*}{ San Dra Tati Wuat } & \multicolumn{12}{|c|}{ 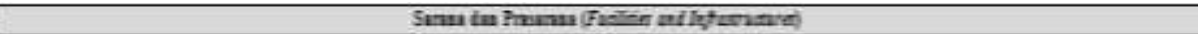 } \\
\hline & & \multicolumn{5}{|c|}{ Seran (Fonilen) } & \multicolumn{7}{|c|}{ Preantelefuraveli } \\
\hline 2 & Desalisakarara & $\sqrt{3}$ & $\sqrt{7}$ & v & $\sqrt{1}$ & $\sqrt{7}$ & $\frac{7}{3}$ & $\sqrt{ }$ & $\sqrt{ }$ & $\sqrt{3}$ & $\sqrt{1}$ & v & $\sqrt{1}$ \\
\hline 3 & Finkag & - & - & - & - & - & - & - & - & - & - & - & - \\
\hline i & Briskama & - & - & - & - & - & $\sqrt{1}$ & $\sqrt{ }$ & $\sqrt{ }$ & - & $\sqrt{2}$ & $\sqrt{7}$ & $\sqrt{7}$ \\
\hline 7 & Bathanana" & - & - & - & - & - & - & - & - & - & - & $\sqrt{1}$ & - \\
\hline I & $\begin{array}{l}\text { Peinaha Wyan } \\
\text { Materg" }\end{array}$ & - & - & - & - & - & $\sqrt{7}$ & $\sqrt{ }$ & $\sqrt{ }$ & - & $\sqrt{ }$ & $\sqrt{7}$ & - \\
\hline I & $\begin{array}{l}\text { Tana Vista An BA } \\
\text { Taghing" }\end{array}$ & - & $\sqrt{7}$ & - & - & $\sqrt{3}$ & $\sqrt{3}$ & $\sqrt{1}$ & $\sqrt{1}$ & - & $\sqrt{ }$ & $\sqrt{ }$ & - \\
\hline
\end{tabular}

Source: Research Process Data, 2018. Note: $(\sqrt{ })$ exists, (-) does not exist, (*) does not cross the river 
The table above shows that DTW which has the strength of facilities and infrastructure are Sei Gohong and Kanarakan Tourism Villages. Both of these tourism villages meet twelve parameters of river tourism facilities and infrastructure adequately for the comfort needs of tourists.

Whereas DTW which has the weakest river tourism destination is Kaja Island. Apart from the fact that this island is a pre-release Orangutan conservation area surrounded by the Rungan river, this place functions more as a destination for environmentalists to wildlife researchers with strict restrictions in development aspects.

\section{Conclusion}

\subsection{Rivertourism Resources}

River Tourism Resources possessed by 10 Tourism Destination Areas (DTW) located in the Strategic Tourism Area (KSP) 2 Tumbang Tahai with the theme of developing Educational and Conservation Tourism are seven out of ten DTWs having island resources, three out of ten DTW has animal resources, five of the ten DTWs have cultural resources and all DTWs have resource management. In general, river tourism resources that are potential in KSP 2 require real efforts in enriching the diversity of endemic fauna typical of Kalimantan in addition to the Orang Utan to become a naturalbased tourism icon. Endemic fauna such as gibbons (Hylobates albibarbis), slow lorises (Bornean nycticebus), proboscis monkeys (Nasalis larvatus), honey bears (Helarctos malayanus) and hornbills / hornbills (Bucerotidae) can be fauna icons that are not owned by other regions and support conservation efforts guarding it from extinction.

\subsection{Tourist Activities}

Tourist Activities that can be carried out at 10 DTW KSP 2 Tumbang Tahai include water based activities such as water skiing, jet boating, personal water craft, low-speed motor boating, fishing, house boating, river rafting, canoeing, and kayaking. Almost all river areas in Kalimantan are not recommended for swimming or diving / snorkelling. The riverbed consists of plant roots so that it is prone to getting caught and the quality of the river water is mostly polluted by mercury from the traditional gold mining process carried out since decades ago.

As for water related land activities that can be done include backpacking, wildlife viewing, hunting, picnicking, and hiking. Tourist activities carried out on the mainland are to enjoy and observe the natural wealth on the banks of rivers and tropical rain forests with all the flora and fauna endemic to the island of Borneo, most of which are not found in other regions in Indonesia.

\subsection{Quality of Riverbank}

The quality of Riverbanks possessed by 10 DTW located in KSP 2 Tumbang Tahai covers the surrounding environment, the availability of open space, activities throughout the year, facility design flexibility to a variety of activities, triggering elements of creativity and pleasure of tourists, accessibility of DTW with rivers, the existence of local identities, the presence of water attractions, the existence of iconic and multifunctional buildings, and the availability of management. Of the ten DTWs that meet the ten qualities of public destinations are Sei Gohong Tourism Villages. Then the Kanarakan and Sei Batu Tourism Villages that meet the nine qualities of public destinations. These three places are located along the Rungan River route that connects urban areas through the Kahayan River in Palangka Raya with surrounding villages. Kanarakan Tourism Village in Bukit Batu 
District can be reached in 60 minutes using a kelotok from the Sei Gohong pier and is the farthest distance from the urban area from KSP 2. In the same area as Sei Gohong Tourism Village there is the Kaja Island DTW which only meets the four quality destinations but has a local identity that is an icon of the endangered fauna, the wild Orang Utan. A visit to Kaja Island about 30 minutes using a boat from Sei Gohong pier will add value to travellers who have an interest in Dayak culture, nature and conservation.

\subsection{Facilitites and Infrastructures}

River tourism facilities and infrastructure owned by 10 DTW located in KSP 2 Tumbang Tahai include accommodation, drinking and eating facilities, rental, interpretation, docks, electricity, clean water, places of worship, health facilities, security, communication networks cellular, and waste disposal, placing Sei Gohong Tourism Village and Kanarakan Tourism Village as DTW that fulfil the twelve aspects of facilities and infrastructure to support tourist comfort. Then Kaja Island does not fulfil any aspect of infrastructure because this area is one of the Orang Utan conservation areas. Facilities and infrastructure can be obtained by tourists when visiting Kaja Island if they use the services of riverboat operators who provide most of the aspects supporting the comfort of tourists.

\subsection{Recommendation}

Based on the identification of the actual conditions described in the previous discussion, the development of tourism areas in KSP 2 based on the potential characteristics available and becoming regional icons can be sharpened by applying thematic tourism areas, such as river tourism, lake tourism, conservation of endangered species and cultural tourism based on zoning division of the region as shown in the figure below.

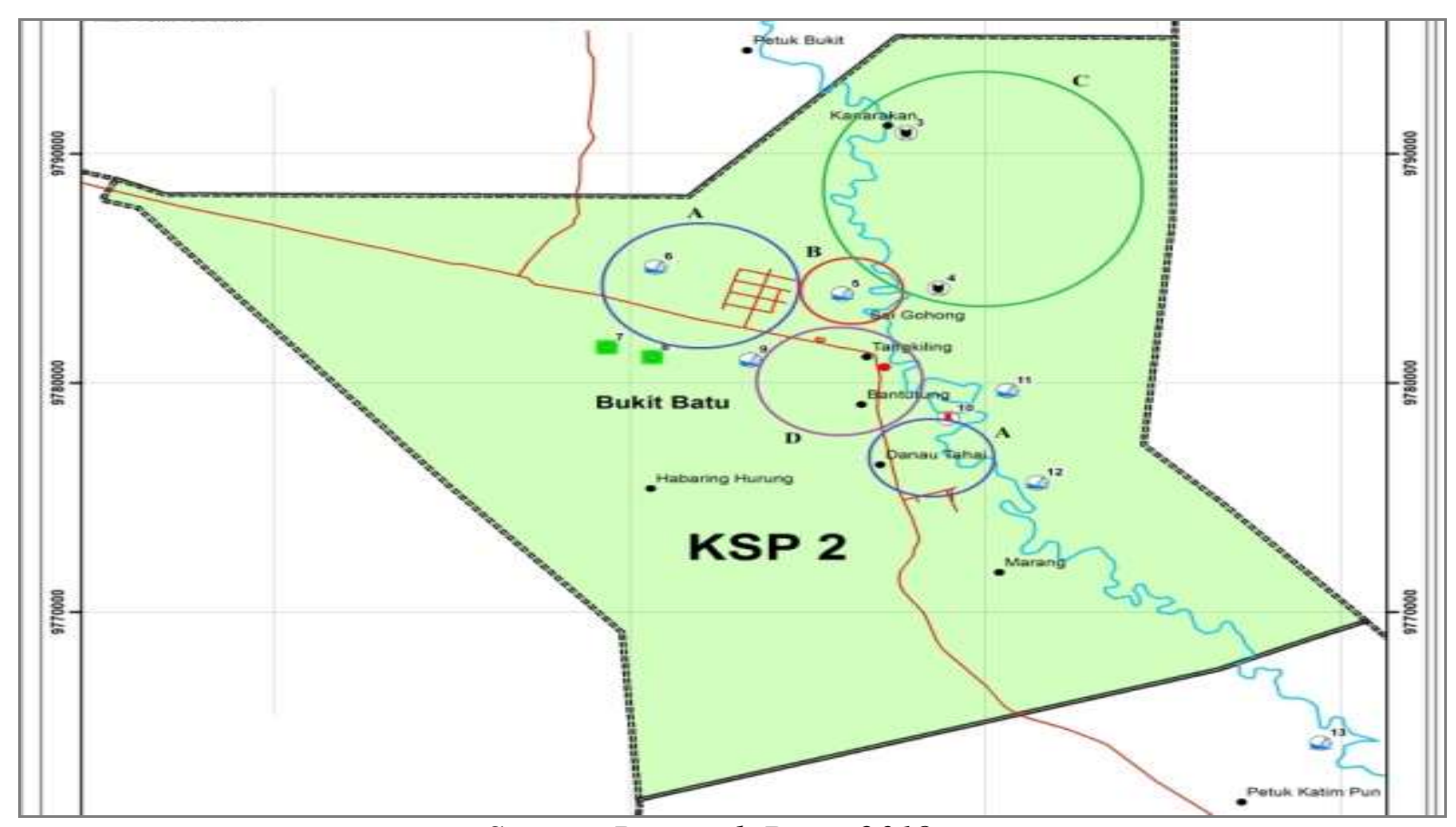

Source: Research Data, 2018.

Figure 4. Distribution of River Tourism Zoning in KSP 2 Tumbang Tahai 
The zoning distribution of the region is described as follows:

1. The core zone (A) is DTW Sei Batu and DTW Danau Tahai, an area of image and concept development that lies behind river tourism, where facilities can be developed commensurate with the concept of river tourism without disturbing environmental sustainability and carrying capacity. Keeping visitors coming to the core zone does not exceed the maximum capacity. In this zone, there are food and drink facilities, small supermarkets, souvenir shops, including jogging track and bicycle facilities.

2. Development zone (B) is the Sei Gohong Tourism Village area with the concept of the development of education and cultural knowledge of indigenous Dayak peoples, agro tourism, geotourism, to historical tourism.

3. Buffer zone (C) is the Kaja Island region and part of the protected forest area of the Kanarakan Village area which is a green zone that functions as a conservation center and the Orang Utan release island in Central Kalimantan.

4. Service zone (D) is the Tangkiling and surrounding areas which is the entrance of tourists to the core zone and other zones in KSP 2 Tumbang Tahai. Types of services in this zone include Provincial crossing roads, public transportation terminals, and water transportation docks.

One of the DTW development plans can be seen in the following figure:

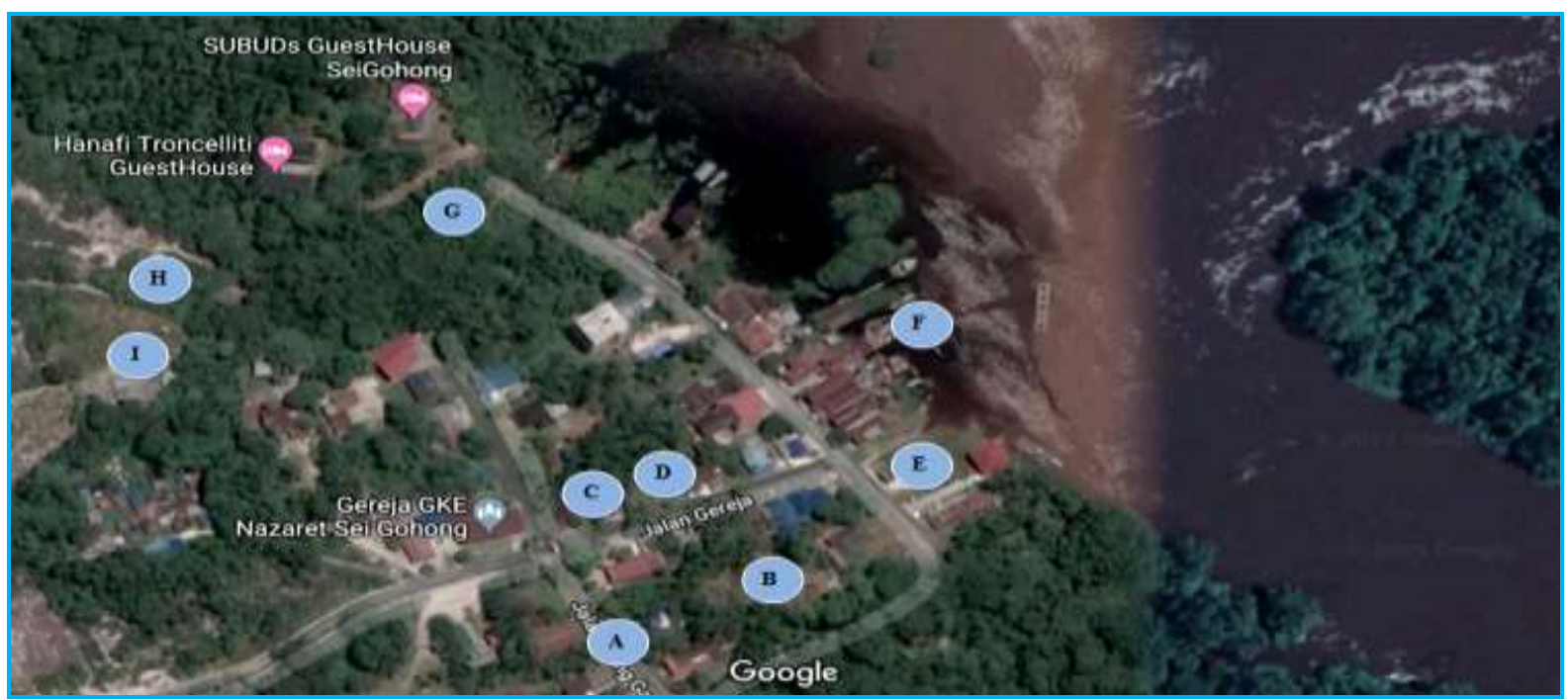

Source: Research Data, 2018.

Info: A Gate, B. Parking, C. Souvenir Shop, D. Supermarket, E. Culinary Area, F. Pier, G. Glamping, H. Forest Orchid Nursery, I. Butterfly

Figure 5. DTW Sei Gohong Tourism Village Development Plan

\section{References}

Alves, L. C. (2011). The growth of 'botos feeding tourism', a new tourism industry based on the boto (Amazon river dolphin) Iniage offrensis in the Amazonas State, Brazil. revistasitientibus.

Amnuay, S. (2013). Developing River Tourism The Upper Mekong. European journal of Business and Social Sciences.

Ankre, R. (2006). Zoning and Opportunity Spectrum Planning in a Discontinuous Environment. European Tourism Research Institute.

Aukerman-Haas. (2004). Water Recreation Opportunities Spectrum (WROS). 
Ayuningtyas, R. A. (2010). Tourism Development Strategies Along the Kapuas River in Pontianak City. Journal of Regional and Urban Planning.

Palangkaraya City BPS. (2018). Palangkaraya City in Figures 2017. Palangkaraya: Central Statistics Agency of Palangkaraya City.

Brierley. (2005). Geomorphology and River Management: Applications of the river Styles Framework. Oxford: Blackwell Science.

Choomgrant, K. (2017). A Vibrant Life by the Chao Phraya River, Northern Bangkok Thailand: The Heritage Tourism Value of Baan Lao Community. Journal of Advances in Economics, Business and Management Research.

Fennel, D. (1999). Ecotourism, An Introduction. New York: Routledge.

Geemente Amsterdam. (2017). Tourism in Amsterdam Metropolitan Area. Amsterdam: Onderzoek, Statistiek Informatieen.

Gutierrez, E. (2005). Linking Communities, Tourism and Conservation. Washington: Conservation International Office.

Hamidah, N. (2010). Potential of the Kahayan Watershed as a Green Space in Palangkaraya City Integrated Area Planning. Inertia of Palangkaraya University.

Hamidi (2008). Qualitative Research Methods. Malang: UMM Press.

Herdiansyah, H. (2011). Qualitative Research Methods For Social Sciences. Jakarta: Salemba Humanika.

Lenasi, A. (2013). Sustainable tourism in Venice. Journal of Haaga Helia's Experience and Wellness Management.

Maryadi, d. (2010). FKIP Thesis Research Guidelines. Surakarta: Surakarta Muhammadiyah University.

Moleong, L. J. (2012). Qualitative Research Methodology Revised Edition. Bandung: PT. Teen Rosdakarya.

Mukti, M. D. (2015). West Brantas River Kediri City Development Strategy as a Regional Tourism Destination to Increase Regional Revenue. Journal of Public Administration.

Ningsih, L. (2014). Analysis of Tourism Marketing in the City of Palangkaraya. Parahyangan University Management Science Journal.

Orams, M. (1999). Marine Tourism, Development, Impact and Management. New York: Routledge.

Palangkaraya City Government. (2009). Palangkaraya City Long Term Development Plan 2008-2028. Palangkaraya: City Government of Palangkaraya.

Prideaux, B. (2009). River Tourism. Oxford: CAB International.

Priono, Y. (2017). The Potentials of Tourism Products in the Development of Tangkiling Tourism Village in Bukit Batu Sub District, Central Kalimantan. Journal of Architecture Perspective Palangkaraya University.

Rusady, R. (2008). Public Relations and Communication Research Methods. Jakarta: PT Raja Grafindo Persada.

Setiawan, B. (2014). Study of River Transportation to Revive the Area of the Kahayan River Palangkaraya City. Diponegoro University Workshop.

Spillane J. J. (1987). Indonesian Tourism History and Prospects. Yogyakarta: Canisius.

Water Science and Technology Board. (2005). The National Academies. Washington: National Academy of Sciences.

Yoeti, Oka A. et al (2006). Cultural Tourism Problems and Solutions. Jakarta: Pradnya Paramita.

Yoeti, Oka A. (1996). Introduction to Tourism Science. Bandung: Space. 
Yulita, Y. (2018, 08 26). Palangkaraya City Tourism Development Present and Future. (N. Dianawati, Interviewer)

Yusof, N. (2013). Rivers, Lakes, and Swamps: Sustainable Approach towards Ecotourism. Proceedings of the 3rd Regional Conference on Tourism Research. Langkawi: University of Science Malaysia. 